\title{
Multilevel Analysis on the Contextual Effect of Village and Sociodemographic Factors on Neonatal Death in Karanganyar, Central Java
}

\author{
Amin Sukoco'), Harsono Salimo²), Yulia Lanti Retno Dewi3) \\ 1)Masters Program in Public Health, Universitas Sebelas Maret \\ 2)Department of Pediatrics, Dr. Moewardi Hospital, Surakarta \\ 3)Faculty of Medicine, Universitas Sebelas Maret
}

\section{ABSTRACT}

Background: Globally, the number of neonatal death in 2018 was 7,000 cases per day. Three-quarters of deaths occurred in the first week of life and $40 \%$ of them died in the first 24 hours after birth. Neonatal death is affected by various factors such as direct factors from the baby and indirect factors from the mother. It is also affected by external factors such as socioeconomic conditions. This study aimed to examine the biological and socio-demographic factors affecting neonatal death in Karanganyar Regency, Central Java.

Subjects and Method: This was a case control study conducted in Karanganyar, Central Java. The population was all infants at neonatal age in Karanganyar Regency. The sample was 200 respondents with 50 cases of neonatal death and 150 infants who were alive during the neonatal period. This study used fixed disease sampling. The dependent variable was neonatal death. The independent variables were Mid-Upper Arm Circumference (MUAC) of the mother, maternal age, maternal education, maternal occupation, total family income, number of maternal deliveries, and the Alert Village level. The data were analyzed using logistic regression analysis with STATA 14.

Results: The risk of neonatal death decreased with maternal MUAC $\geq 23.5 \mathrm{~cm}(b=-1.19 ; 95 \%$
$\mathrm{CI}=-2.02$ to $-0.36 ; \mathrm{p}=0.005)$; maternal age between $20-35$ years $(b=-0.98 ; 95 \% \mathrm{CI}=-1.76$ to -0.20; $\mathrm{p}=0.014)$; maternal education $\geq$ Senior High School $(b=-0.67 ; 95 \% C I=-1.46$ to $0.12 ; p=$ o.097); unemployed mothers $(b=-1.07 ; 95 \%$ $\mathrm{CI}=-1.95$ to $-0.19 ; \mathrm{p}=0.017)$; total family income $\geq \operatorname{Rp~1,833,000~(b=-1.17;95\% CI=-2.04}$ to $-0.30 ; \mathrm{p}=0.008)$; and the number of birth deliveries of $2-4(b=-0.79 ; 95 \% C I=-1.53$ to $0.05 ; \mathrm{p}=0.036$ ). The level of Alert Village had a very low effect on the risk of neonatal death (ICC was <0.01\%).

Conclusion: Neonatal mortality is affected by maternal MUAC, maternal age, maternal education, maternal occupation, total family income, and number of maternal deliveries. The level of Alert Village has a very low effect on neonatal death.

Keywords: Neonatal death, sociodemographic, mother

\section{Correspondence:}

Amin Sukoco. Masters Program in Public Health, Universitas Sebelas Maret, Jl. Ir. Sutami 36A, Surakarta 57126, Indonesia. Email: soekotjo78@gmail.com. Mobile: +6281329387610 .

\section{Cite this as:}

Sukoco A, Salimo H, Dewi YLR (2021). Multilevel Analysis on the Contextual Effect of Village and Sociodemographic Factors on Neonatal Death in Karanganyar, Central Java. J Matern Child Health. 06(02): 207-219. https://doi.org/10.26911/thejmch.2021.06.02.08.

cc) (i) (2) Journal of Maternal and Child Health is licensed under a Creative Commons Attribution-NonCommercial-ShareAlike 4.0 International License.

BACKGROUND
One of the important indicators for
assessing the level of welfare including the
degree of health and quality of life in

Indonesia is information on child death which consists of the Neonatal Mortality Rate (NMR), the Infant Mortality Rate (IMR), and the Children under-five 
Mortality Rate (CMR). Child mortality rates help to identify susceptible groups who are at higher risk of dying. In addition, it is an input for strategies in reducing this risk, such as maternal health care and family planning programs that play a role in the mother and child survival (National Family Planning Coordination Board and Central Bureau of Statistics, 2018).

Globally, in 2018, there were 7000 babies aged 0-28 days who died every day. Three-quarters of neonatal deaths occurred in the first week of life, and $40 \%$ of them died in the first 24 hours after birth. Neonatal death is closely related to the quality of delivery care and handling of newborns which was less than optimal after and the first few days after birth (WHO, 2019).

Based on the results of the Indonesian Demographic and Health Survey (IDHS) in 2017, the Neonatal Mortality Rate (IMR) in 2017 was 15 per 1000 live births. It showed that 1 of 67 children died in the first month of life. This rate decreased when compared to the IDHS results in 2002-2003, which was 20 per 1000 live births (National Family Planning Coordination Board and Central Bureau of Statistics, 2018).

Efforts to reduce IMR are very important because neonatal death contributed $73 \%$ of infant death in Central Java. However, the trend of neonatal death in Central Java from 2014 - 2018 tended to decrease, from 7.5 per 1000 live births (KH) to 6.1 per 1000 live births (Central Java Health Office, 2019).

Neonatal death cases in Karanganyar from 2014-2018 fluctuated: 87 cases in 2014, 115 cases in 2015, 29 cases in 2016, 113 cases in 2017, 61 cases in 2018. The highest causes of neonatal death in Karanganyar in 2018 sequentially were low birth weight by 27 cases, asphyxia by 12 cases, other causes by 12 cases, sepsis by 7 cases, and congenital abnormalities by 3 cases (Karanganyar Health Office, 2019).

There were so many programs and activities carried out by the central government, provincial governments, and district/ city governments to reduce the risk of maternal and child mortality. One of these programs was Alert Village, which has been initiated by the Central Government since 2006. This Alert Village aimed to accelerate the realization of rural and urban village communities who care, who are responsive, who can recognize, prevent, and overcome health problems faced independently. Therefore, the degree of health increased (Ministry of Health, 2010).

The Alert Village in Karanganyar has been activated since 2006 in line with the Central Government Program. Until 2018, there were 177 villages/wards in Karanganyar that have become 100\% standby villages/wards. Based on the data of 2018 in Karanganyar, $11.86 \%$ of the 177 villages/ wards were independent, 22.60\% were full, 40.68\% were intermediate, and $24.86 \%$ were main (Karanganyar Health Office, 2019).

\section{SUBJECTS AND METHOD}

\section{Design of the Study}

This study was an analytical observational study with a cross-sectional approach. This study used multilevel logistic regression analysis.

\section{Population and Sample}

The population of this study was all infants at the neonatal age in Karanganyar. This study was conducted from January to December 2019.

\section{Variables of the Study}

The variables observed in this study were neonatal death, maternal MUAC, maternal age, maternal education, maternal occupation, total family income, the number of 
maternal deliveries, and level of Alert Village.

\section{Operational Definition of Variables} Neonatal death was the death of a newborn aged 0-28 days in the first month after birth. The measuring instrument was the data of the patient's medical record from the child's health report application notes. The data scale was categorical data with code $\mathrm{o}=$ surviving infants after the neonatal period and code $1=$ dying infants at the age of 0-28 days.

Maternal nutritional status was the nutritional status of the mother during pregnancy. The measuring instrument was a questionnaire by observing the secondary data from the MCH Handbook. The data scale was categorical data. Code $\mathrm{o}=$ mother with poor nutritional status (chronic energy deficiency) if MUAC $<23.5 \mathrm{~cm}$; and $1=$ mothers with good nutritional status if MUAC $\geq 23.5 \mathrm{~cm}$.

Maternal age was the age of the mother when the data were collected. The measuring instrument was a questionnaire. The data scale was continuous. The data were converted into dichotomous data to facilitate the analysis. Code $\mathrm{O}=$ age at risk $<20$ or $>35$ years; and $1=$ age of the mother that was not at risk between 20-35 years.

Maternal education was the highest level of formal education a mother has taken. The measuring instrument was a questionnaire. The data scale was continous. The data were converted into dichotomous data to facilitate the analysis. Code $\mathrm{o}=$ low education (Primary School-Junior High school / equivalent); and $1=$ higher education (Senior High School, diploma, higher education).

Maternal occupation was the total income received by the family from both the head of the family and family members as measured by the Minimum Wage of Karanganyar Regency in 2019. The mea- suring instrument was a questionnaire. The data scale was continuous. The data were converted into dichotomous data to facilitate the analysis. Code $\mathrm{O}=$ employed mother; and $1=$ unemployed mother.

Family income was the intake that the baby received. It could be breast milk for 6 months or additional food at the right age. The measuring instrument was a questionnaire. The data scale was continuous. The data were converted into dichotomous data to facilitate the analysis. Code $\mathrm{O}=$ low Minimum Wage <Rp 1,833,00o; and 1= high Minimum Wage $\geq \operatorname{Rp} 1,833$,ooo.

Number of deliveries was the number of maternal deliveries including the delivery histories which were the study subject. The measuring instrument was a questionnaire. The data scale was continuous. The data were converted into dichotomous data to facilitate the analysis. Code $\mathrm{O}=$ at-risk maternal delivery ( 1 or $\geq 5$ ); and $1=$ nonrisk maternal delivery (2-4).

Contextual of the Alert Village was a village whose inhabitants had readiness of resources, the ability, and willingness to prevent and overcome health problems, disasters, and emergencies independently. The measuring instrument was the secondary of the Alert Village category. The data scale was categorical data. Code $1=$ independent Alert Village; $2=$ full; 3: intermediate; 4= main.

\section{Instrument of the Study}

The instrument used to collect the primary data was a closed questionnaire (checklist) containing the identity according to the study needs.

\section{Data Analysis}

Univariate analysis described the distribution of the variables studied. The data were grouped according to the type of data. The continuous data were presented with mean, standard deviation, minimum, and maximum values. The dichotomous data were 
Sukoco et al./ Contextual Effect of Village and Sociodemographic Factors on Neonatal Death

inserted into the frequency distribution table. Bivariate analysis aimed to determine the relationship between independent and dependent variables using the Chi-square test. Multivariate analysis described the relationship of the effect among variables. Multivariate analysis was conducted using multilevel logistic regression analysis.

\section{Research Ethics}

This study paid attention to the basic principles of research ethics. This study has

Table 1. The characteristics of the sample (continuous data)

\begin{tabular}{lccccc}
\hline \multicolumn{1}{c}{ Variable } & n & Mean & SD & Min. & Max. \\
\hline Mid-Upper Arm & 200 & 25.54 & 3.05 & 20 & 37.5 \\
Circumference (MUAC) (cm) & & & & & \\
Maternal age (years) & 200 & 29.75 & 5.91 & 18 & 43 \\
Family income (Rp) & 200 & $2,942,140$ & $1,789,139$ & $1,000,000$ & 15, ooo, 000 \\
Delivery (time) & 200 & 2.13 & 1.19 & 1 & 6 \\
\hline
\end{tabular}

Table 2. The characteristics of the sample (categorical data)

\begin{tabular}{|c|c|c|}
\hline Characteristic & $\mathbf{n}$ & $\%$ \\
\hline \multicolumn{3}{|l|}{ Sex of infants } \\
\hline - Male & 113 & 56.50 \\
\hline - Female & 87 & 43.50 \\
\hline \multicolumn{3}{|l|}{ Mid-Upper Arm Circumference (MUAC) } \\
\hline$-\quad<23.5 \mathrm{~cm}$ & 38 & 19.00 \\
\hline$-\quad \geq 23.5 \mathrm{~cm}$ & 162 & 81.00 \\
\hline \multicolumn{3}{|l|}{ Maternal age } \\
\hline$-\quad<20$ or $>35$ years & 48 & 24.00 \\
\hline - 20-35 years & 152 & 76.00 \\
\hline \multicolumn{3}{|l|}{ Maternal education } \\
\hline - $\quad<$ Senior High School & 87 & $43 \cdot 50$ \\
\hline - $\quad \geq$ Senior High School & 113 & 56.50 \\
\hline \multicolumn{3}{|l|}{ Maternal education } \\
\hline - Employed & 73 & 36.50 \\
\hline - Unemployed & 127 & 63.50 \\
\hline \multicolumn{3}{|l|}{ Total family income } \\
\hline - Low minimum wage $(<\operatorname{Rp} 1,833,000)$ & 68 & 34.00 \\
\hline - $\quad$ High minimum wage ( $\geq \operatorname{Rp} 1,833,000)$ & 132 & 66.00 \\
\hline \multicolumn{3}{|l|}{ Number of birth deliveries } \\
\hline$-\quad 1$ or $\geq 5$ & 86 & 43.00 \\
\hline$-\quad 2-4$ & 114 & 57.00 \\
\hline \multicolumn{3}{|l|}{ Level of Alert Village } \\
\hline - Independent & 24 & 12.00 \\
\hline - Full & 96 & 48.00 \\
\hline - Intermediate & 56 & 28.00 \\
\hline - Main & 24 & 12.00 \\
\hline
\end{tabular}


Sukoco et al./ Contextual Effect of Village and Sociodemographic Factors on Neonatal Death

Table 1 shows that the mean value of maternal MUAC as the variable was 25.54, the standard deviation was 3.05, the minimum value was 20 , and the maximum value was 37.5 ; the mean value of maternal age as the variable was 29.75 , the standard deviation was 5.91 , the minimum value was 18 , and the maximum value was 43 ; the mean value of family income as the variable was IDR 2,942,140, the standard deviation was IDR $1,789,139$, the minimum value was IDR 1,000,000, and the maximum value was IDR 15,000,000; the mean value of maternal deliveries as the variable was 2.13, the standard deviation was 1.19, the minimum value was 1 , and the maximum value was 6 .

Table 2 shows that most of the study subjects were male by 113 people (56.5\%), most of the study subjects with MUAC $\geq$
$23.5 \mathrm{~cm}$ were 162 people ( $81 \%)$, most of the study subjects were 152 mothers (76\%) aged 20-35 years old, most of the study subjects with $\geq$ Senior High Education were 113 mothers (56.5\%), most of the study subjects who were unemployed were 127 people (63.5\%), most of the study subjects who had total family income with a high minimum wage $\geq$ IDR 1,833 ,ooo, were 132 people (66\%), most of the study subjects with a total of 2-4 maternal deliveries were 114 people (57\%), and most of the Alert Village level who were full were 96 people (48\%).

\section{Bivariat analysis}

Bivariate analysis aimed to see the relationship between the independent variables and the dependent variable which was analyzed using the Chi-square test.

Table 3. The result of the Chi-square of the effect of MUAC, maternal age, education, occupation, family income, and birth of deliveries on neonatal death

\begin{tabular}{|c|c|c|c|c|c|c|c|c|c|c|}
\hline \multirow{3}{*}{$\begin{array}{l}\text { Independent } \\
\text { Variable }\end{array}$} & \multicolumn{4}{|c|}{ Neonatal death status } & \multirow{2}{*}{\multicolumn{2}{|c|}{ Total }} & \multirow{3}{*}{$\mathbf{O R}$} & \multicolumn{2}{|c|}{$(95 \%) \mathrm{CI}$} & \multirow{3}{*}{$\mathbf{p}$} \\
\hline & \multicolumn{2}{|c|}{$\begin{array}{c}\text { Surviving } \\
\text { infants }\end{array}$} & \multicolumn{2}{|c|}{$\begin{array}{c}\text { Dying } \\
\text { infants }\end{array}$} & & & & \multirow{2}{*}{$\begin{array}{l}\text { Lower } \\
\text { limit }\end{array}$} & \multirow{2}{*}{$\begin{array}{l}\text { Upper } \\
\text { limit }\end{array}$} & \\
\hline & $\mathbf{n}$ & $\%$ & $\mathbf{n}$ & $\%$ & $\mathbf{n}$ & $\%$ & & & & \\
\hline \multicolumn{11}{|l|}{ MUAC } \\
\hline$-<23.5 \mathrm{~cm}$ & 22 & 57.9 & 16 & 42.1 & 38 & 100 & \multirow{2}{*}{0.37} & \multirow{2}{*}{0.16} & \multirow{2}{*}{0.83} & \multirow{2}{*}{0.007} \\
\hline $\begin{array}{l}-\geq 23.5 \mathrm{~cm} \\
\text { Age }\end{array}$ & 128 & 79.0 & 34 & 21.0 & 162 & 100 & & & & \\
\hline$-<20$ or $>35$ years & 30 & 62.5 & 18 & 37.5 & 48 & 100 & \multirow{2}{*}{0.44} & \multirow{2}{*}{0.21} & \multirow{2}{*}{0.96} & \multirow{2}{*}{0.022} \\
\hline $\begin{array}{l}\text { - 20-35 years } \\
\text { Education }\end{array}$ & 120 & 78.9 & 32 & 21.1 & 152 & 100 & & & & \\
\hline $\begin{array}{c}-<\text { Senior High } \\
\text { School }\end{array}$ & 58 & 66.7 & 29 & 33.3 & 87 & 100 & \multirow{3}{*}{0.46} & \multirow{3}{*}{0.22} & \multirow{3}{*}{0.92} & \multirow[b]{2}{*}{0.017} \\
\hline $\begin{array}{l}\text { - } \geq \text { Senior } \quad \text { High } \\
\text { School }\end{array}$ & 92 & 81.4 & 21 & 18.6 & 113 & 100 & & & & \\
\hline \multicolumn{8}{|l|}{ Occupation } & & & \\
\hline - Employed & 53 & 72.6 & 20 & 27.4 & 73 & 100 & \multirow{2}{*}{0.82} & \multirow{2}{*}{0.40} & \multirow{2}{*}{1.68} & \multirow{2}{*}{0.553} \\
\hline $\begin{array}{l}\text { - Unemployed } \\
\text { Family income }\end{array}$ & 97 & 76.4 & 30 & 23.6 & 127 & 100 & & & & \\
\hline $\begin{array}{l}\text { - Low minimum } \\
\text { wage }\end{array}$ & 43 & 63.2 & 25 & 36.8 & 68 & 100 & \multirow{3}{*}{0.40} & \multirow{3}{*}{0.20} & \multirow[b]{2}{*}{0.82} & \multirow[b]{2}{*}{0.006} \\
\hline $\begin{array}{l}\text { - High minimum } \\
\text { wage }\end{array}$ & 107 & 81.1 & 25 & 18.9 & 132 & 100 & & & & \\
\hline \multicolumn{9}{|c|}{ Number of deliveries } & & \\
\hline-1 or $\geq 5$ & 59 & 68.6 & 27 & 31.4 & 86 & 100 & \multirow{2}{*}{0.55} & \multirow{2}{*}{0.27} & 1.10 & 0.070 \\
\hline$-2-4$ & 91 & 79.8 & 23 & 20.2 & 114 & 100 & & & 1.10 & 0.070 \\
\hline
\end{tabular}


Table 3 below presents the results of the bivariate analysis using the Chi-square test on the effect of maternal MUAC, maternal age, maternal education, maternal occupation, total family income, and number of maternal deliveries on the risk of neonatal death.

Table 3 shows that mothers with MUAC $\geq 23.5 \mathrm{~cm}$ were 0.37 times less likely to cause neonatal death than mothers with MUAC $<23.5 \mathrm{~cm}(\mathrm{OR}=0.37 ; 95 \% \mathrm{CI}=0.16$ to o.83; $\mathrm{p}=0.007$ ); Mothers aged 20-35 years were 0.44 times less likely to cause neonatal death than mothers aged $<20$ or $>35$ years $(\mathrm{OR}=0.44 ; 95 \% \mathrm{CI}=0.21$ to $0.96 ; \mathrm{p}=$ 0.022); Mothers with $\geq$ Senior High School education were 0.46 times less likely to cause neonatal death than mothers with $<$ Senior High School education $(\mathrm{OR}=0.46$; $95 \% \mathrm{CI}=0.22$ to $0.92 ; \mathrm{p}=0.017$ ).

Unemployed mothers were 0.82 times less likely to cause neonatal death than mothers who were employed $(\mathrm{OR}=0.82$; $95 \% \mathrm{CI}=0.40$ to $1.68 ; \mathrm{p}=0.553)$; The total family income with a high Minimum Wage ( $\geq$ Rp 1,833,000) was 0.40 times less likely to cause neonatal death than mothers with total family income <IDR 1,833,000 (OR= $0.40 ; 95 \% \mathrm{CI}=0.20$ to $0.82 ; \mathrm{p}=0.006$ ); The number of maternal deliveries of the second to the fourth had a 1.8 times less risk of causing neonatal death than the number of maternal delivery of the first to $\geq 5(\mathrm{OR}=0.55 ; 95 \% \mathrm{CI}=0.27$ to $1.10 ; \mathrm{p}=$ 0.070 ).

\section{Multivariate analysis}

This study used a multilevel logistic regression analysis model where the variables at level 1 consisted of maternal
MUAC, maternal age, maternal education, maternal occupation, amount of family income, and the number of maternal deliveries, while at level 2 was the Alert Village level.

Table 4 shows that there was a relationship between several variables on neonatal death. Neonates from mothers with MUAC $\geq 23.5 \mathrm{~cm}$ had a logodd (probability) of dying by 1.19 lower than maternal MUAC $<23.5 \quad \mathrm{~cm} \quad(\mathrm{~b}=-1.19$; 95\%CI $=-2.02$ to $-0.36 ; \mathrm{p}=0.005$ ); Neonates from mothers aged 20-35 years had a logodd (probability) of dying by 0.98 units lower than mothers aged $<20$ or $>35$ years ( $\mathrm{b}=-0.98 ; 95 \% \mathrm{CI}=-1.76$ to $-0.20 ; \mathrm{p}=0.014)$; Neonates from mothers with $\geq$ Senior High School education had a logodd (probability) of dying by 0.67 units lower than the mothers with $<$ Senior High School education $(\mathrm{b}=-0.67 ; 95 \% \mathrm{CI}=-1.46$ to $0.12 ; \mathrm{p}=$ 0.097); Neonates from unemployed mothers had a logodd (probability) of dying by 1.07 units lower than employed mothers $(b=-1.07 ; 95 \% \mathrm{CI}=-1.95$ to $-0.19 ; \mathrm{p}=0.017)$; Neonates from mothers with total family income $\geq \mathrm{Rp}$ 1,833,000 had a logodd (probability) of dying by 1.17 units lower than the total family income <IDR $1,833,000$ ( $b=-1.17 ; 95 \% \mathrm{CI}=-2.04$ to -0.30 ; $\mathrm{p}=0.008$ ); Neonates from mothers with the number of maternal deliveries by $2-4$ times had a logodd (likelihood) of death of 0.79 units lower than the number of maternal deliveries by 1 or $\geq 5$ times ( $b=-0.79 ; 95 \%$ $\mathrm{CI}=-1.53$ to $-0.05 ; \mathrm{p}=0.036$ ). Meanwhile, the contextual effect of the Alert Village was very low on the risk of neonatal death (ICC was $<0.01 \%$ ). 
Sukoco et al./ Contextual Effect of Village and Sociodemographic Factors on Neonatal Death

Table 4. The result of multilevel logistic regression analysis of the contextual effect of Alert Villages and socio-demographic determinants on neonatal death

\begin{tabular}{lcccc}
\hline & Regression & \multicolumn{2}{c}{$\mathbf{9 5 \%}$ CI } & \\
Independent Variable & coefficient & $\begin{array}{c}\text { Lower } \\
\text { Limit }\end{array}$ & $\begin{array}{c}\text { Upper } \\
\text { Limit }\end{array}$ & p \\
\hline Fixed Effect & & & & \\
MUAC ( $\geq 23.5 \mathrm{~cm})$ & -1.19 & -2.02 & -0.36 & 0.005 \\
Age (20-35) & -0.98 & -1.76 & -0.20 & 0.014 \\
Education ( $\geq$ Senior High School) & -0.67 & -1.46 & 0.12 & 0.097 \\
Occupation (unemployed) & -1.07 & -1.95 & -0.19 & 0.017 \\
Family income ( $\geq$ Rp 1,833,000) & -1.17 & -2.04 & -0.30 & 0.008 \\
Number of deliveries (2-4) & -0.79 & -1.53 & -0.05 & 0.036 \\
Constant & 2.65 & 1.13 & 4.16 & 0.001 \\
Random Effect & & & & \\
Alert Village & & & & \\
Var (Constant) & $<0.001$ & & & \\
N observation & 200 & & & \\
N group & 25 & & & \\
Log Likelihood & -96.92 & & & \\
LR test vs logistic regression & p<0.001 & & & \\
Intra Class Correlation (ICC) & $<0.01 \%$ & & & \\
\hline
\end{tabular}

\section{DISCUSSION \\ 1. The effect of maternal MUAC on neonatal death}

Mid-Upper Arm Circumference (MUAC) was an anthropometric measure that describes the nutritional status of pregnant women. MUAC was one of the measuring instruments to identify $\mathrm{CED}$ which was quite good. Pregnant women with MUAC $<23.5 \mathrm{~cm}$ indicated that the mother had CED (Chronic Energy Deficiency). CED was caused by an imbalance among nutritional fulfillment, thus causing LBW for babies (Pinem, 2009; Nurmayanti et al., 2017).

CED was caused by dietary factors (the elements of variety and portions that were unfulfilled). CED or malnutrition status indicated that the mother had malnutrition for a long time. It would cause the nutritional needs for the growth and development of the fetus in the uterus to experience obstacles. Nutritional factors were considered as one of the determinants of maternal and fetal health. Maternal nutritional status determined the development of the fetus in the uterus. CED caused stunted fetal growth, low birth weight, impaired growth and development of vital organs, and increased the risk of infants' morbidity and mortality (LBW) (Moore et al., 2004; Azizah \& Adriani, 2018; Puspitaningrum, 2018; Meltzer et al., 2011).

The relationship between nutritional status and LBW is in line with a study conducted by Wigunantiningsih and Fakhidah (2017) that the nutritional status of pregnant women affected the infant weight. Malnutrition during pregnancy was an important factor that should be the focus of attention of every health personnel in decreasing neonatal death. The data showed that the higher the number of malnourished mothers during pregnancy, the more infants died in the first 28 days of birth (Amuka et al., 2019). 
There was a significant relationship between socio-economic and environmental factors of mothers and the birth weight of newborns. Mothers who did not have formal education, in rural areas far from health care facilities, aged 20 years old at delivery, and had a low monthly income were identified as risk factors for low birth weight. One of the strategies to reduce the risk of LBW was by controlling the gestational age, improving the socio-economic condition of the family, and improving the environmental conditions in the family and work environment (Demelash et al., 2015; Kaboré et al., 2016).

\section{The effect of maternal age on neonatal death}

The risk of neonatal death was affected by various factors, including factors coming from the mother, baby, environment, and health care. One of the maternal factors that increased the risk of neonatal death was the age at delivery. Pregnancy and delivery at the age $<20$ or $\geq 35$ years increased the risk of death in mothers and babies (Manuaba et al., 2009; Anggondowati et al., 2017; Ministry of Health, 2018).

Pregnancy at $\geq 35$ years of age increased the risk of having a baby with congenital defects, chromosomal abnormalities, infection, and birth trauma. Maternal age $<20$ years or $>35$ years was at risk of giving birth to a baby with asphyxia. Maternal age during pregnancy also increased the risk of anemia. The older the maternal age during pregnancy, the more increase the risk of anemia in mothers. Anemia in pregnancy was one of the factors causing LBW. Asphyxia, LBW, birth trauma, infection, and congenital abnormalities or defects were the direct causes of neonatal death (Curtis, 1999; Wigunantiningsih and Fakhidah, 2017; Paramitasari et al., 2018).

According to a study conducted by Akinyemi et al., (2015), the use of antenatal care and biodemographic factors such as gestational distance, maternal age, and birth size were important determinants of neonatal death. Babies born to mothers aged <20 years or >35 years had a higher risk of death by $50 \%$. The increased risk of neonatal death was $14 \%$ higher for neonates born to mothers aged $<18$ years than those born to older mothers (Mekonnen et al., 2013). In addition, there was a lower risk of death for infants born to mothers aged 25 34 years compared to the mothers aged 1224 years (Maniruzzaman et al., 2018).

\section{The effect of maternal education on neonatal death}

Based on the statistical result that was close to significant, there was a relationship or effect between education level and neonatal death, but the relationship was not quite strong. Descriptive analysis showed that $56.50 \%$ of the respondents had secondary and upper secondary education levels. Maternal education was one of the indirect factors causing maternal and perinatal mortality. The level of education was one of the predisposing factors affecting knowledge and attitude towards health (Prawirohardjo, 2009).

Infants born to mothers with secondary or higher education were associated with a $32 \%$ reduced risk of neonatal death compared to uneducated mothers. Education for women was the foundation for improving health. In addition, maternal education was essensial to improve neonatal survival. Improving women education was a long-term strategy for improving pregnancy outcomes and neonatal survival (Mekonnen et al., 2013).

Women with low education levels would have a higher risk of giving birth to low birth weight. This is related to adjustment to meeting the needs for antenatal care (Mekonnen et al., 2013; Nurahmawati et al., 2017). Mothers who had secondary or 
higher education had a logodd of decreasing neonatal death with an $\mathrm{AOR}=$ $0.51 ; 95 \% \mathrm{CI}=0.32$ to 0.83 and $\mathrm{p}=0.007$, compared to uneducated mothers (Abir et al., 2015).

\section{The effect of maternal occupation on neonatal death}

Based on the result of the multivariate analysis conducted to determine the various demographic and health care factors affecting neonatal, infant, and child mortality, $71 \%$ of child deaths occurred in the neonatal period. Employed mothers had a higher possibility of the risk of neonatal mortality with an OR value by 1.48 , the risk of infant mortality with an OR value by 1.51 , and child mortality with an OR value by 1.46 than unemployed mothers (Helova et al., 2016).

The work environment could create health problems for women. Reproductive health problems could be experienced by employed women with mild to severe levels. Some disorders that could be experienced by employed women were menstrual pattern disorders, infertility, premature birth, breastfeeding, and other disorders. In addition, employed mothers had little time to care for themselves and their babies. Pregnancy would affect the quality of antenatal care performed, thus affecting the fetus and increasing the risk of neonatal death. Benefit payments for mothers on maternity leave could reduce neonatal death by reducing maternal work pressure. This action provided more financial support for the family. Neonatal care required intensive care when the mother was experiencing work pressure that made it impossible for the mother to care for her baby (Maniruzzaman et al., 2018).

According to a study (Abir et al., 2015), employed mothers increased the likelihood of the risk of neonatal mortality with values of $(\mathrm{AOR}=1.35 ; 95 \% \mathrm{CI}=1.01$ to $1.80 ; \mathrm{p}=$
0.040) with a significance level of $95 \%$. This showed that employed mothers had a risk of neonatal death 1.35 times higher than unemployed mothers.

\section{The effect of total family income on neonatal death}

Based on the results of the univariate data processing, 107 respondents had income of $\geq$ the Regency Minimum Wage. According to a study (Shibre et al., 2020), positive economic growth in Ethiopia has reduced the neonatal mortality rate in that country where studies were conducted in 20002016. Family or household income was income received by a household, coming from the head of the family or from family members. Family income was an indirect factor causing maternal and perinatal mortality and morbidity (Prawirohardjo, 2009).

Family income is linked to the family's ability to meet basic needs and obtain health care. High family income would reduce the risk of LBW because the mother would have low stress compared to low/lower family income (Trisnawati et al., 2018). This study is in line with the results of other studies that the father's education level had a negative correlation with neonatal mortality. Father's education showed the highest and significant coefficient of improvement in socio-economic conditions and child mortality (Maniruzzaman et al., 2018). This study is in line with Kc et al. (2019) that the results of the multivariate analysis of all variables showed that wealth status (family economic conditions), residence, province, and ecological zone and ethnicity was related to neonatal death. The neonatal mortality rate for women in the poorest quintile was $\mathrm{AOR}=1.37,95 \% \mathrm{CI}=$ 1.21 to 1.54 . The better understanding of the influential factors across wealth quintiles was important for prioritizing interventions needed to improve neonatal survival. 


\section{The effect of the number of mater- nal deliveries on neonatal death}

Neonates from mothers with the number of deliveries by 2-4 times had a 0.79 lower likelihood of neonatal death than mothers with the number of deliveries by 1 or $\geq 5$ times. This study is in line with Maniruzzaman et al. (2018) that neonatal mortality was affected by birth order. The result was statistically significant: from 8753 respondents, 8247 neonates were alive and 506 neonates died. Based on the number of neonates who died, 442 cases (87.40\%) came first, while the rest came second, and so on.

Neonatal death is a health problem that occurs in developing countries. The causes of neonatal death vary widely and often depend on individual health services and health habits. The common causes of neonatal death are infectious disease, preterm birth, and asphyxia (Garba et al., 2017). This study is in line with (Akinyemi et al., 2015) who used a simple regression formula to assess factors associated with neonatal mortality that the first, fourth birth or more had a higher risk of death in the neonatal period compared to the second up to third birth. In assessing the effect of bio-demographic factors, male sex and high birth order by 4 and above were risk factors for neonatal death.

\section{The contextual effect of Alert Village on neonatal death}

The result of this study showed that the contextual level of the Alert Village was very low on the risk of neonatal death. The result of this study is in line with a study (Suryani, 2011) that there was no relationship between the Alert Village level and infant mortality. It showed that the higher the Alert Village level, the infant mortality cases were not lower or almost the same. Many factors affected infant mortality, including maternal age at the delivery process, maternal education, birth attendants, the baby's breathing condition, birth weight, prematurity, ANC visits, and breastfeeding.

The result of this study was not in line with Kc et al. (2019), which stated that women who lived in rural areas had a higher risk of neonatal mortality (AOR= $1.28 ; 95 \% \mathrm{CI}=1.13$ to 1.44 ). A study by $\mathrm{Wu}$ et al. (2016) stated that neonatal death in Shenyang decreased significantly from 1997 to 2014 which occurred in urban areas by 3.67 per 1,000 live births. However, there were 6.68 per 1000 live births in rural areas. All villages in Karanganyar Regency were Alert Villages but the guidance for these villages was only at the beginning of its formation. Therefore, the concept of Alert Villages, namely community empowerment in the health sector, has not been implemented by the Alert Village team at the village/wards level. It was expected that the village communities were able to identify and solve health problems in their area (Sulaeman et al., 2012).

The factors inhibiting the activities of the Alert Village were the lack of regeneration of health cadres, the apathetic residents, the busyness of the organization, and the Village Health Post (Poskesdes) that was not functioning properly. Alert Village would be successful if there was an active role from the community members in the villages/wards area. Therefore, the community would strive for community health independently, medical emergency treatment through the effort of health community-based services, and increase cooperation among the communities (Surya and Sunarto, 2016). Alert Village would run poorly if there is no change in the organizational structure in the form of village forums, village regulations regarding Alert Villages, and community self-help. Socialization of the village regulations needs to be 
Sukoco et al./ Contextual Effect of Village and Sociodemographic Factors on Neonatal Death

done to encourage community participation; in addition, community self-help is important to encourage community independence (Maretalinia and Wibowo, 2019).

\section{AUTHOR CONTRIBUTION}

Amin Sukoco was the main researcher who carried out the study, collected the data, formulated the articles, and processed the data. Harsono Salimo arranged the background and discussed the study. Yulia Lanti Retno Dewi formulated the study framework and analyzed the data.

\section{CONFLICT OF INTEREST}

There is no conflict of interest in this study.

\section{FUNDING AND SPONSORSHIP}

This study used the Budget from the Agency for Development and Empowerment of Health Professionals, the Indonesian Ministry of Health in 2020.

\section{ACKNOWLEDGEMENT}

The researcher expressed gratitude to the Head of the Karanganyar Regency Health Office, the Head of the UPT Community health center in the Karanganyar Regency area for allowing us to conduct this study. We would like to thank all respondents who have been willing to be the study subjects.

\section{REFERENCE}

Abir T, Agho KE, Page AN, Milton AH, Dibley MJ (2015). Risk factors for under-5 mortality: evidence from Bangladesh Demographic and Health Survey, 2004-2011. BMJ Open, 5: 19. https://doi.org/10.1136/bmjopen2014-006722.

Akinyemi JO, Bamgboye EA, Ayeni O (2015). Trends in neonatal mortality in Nigeria and effects of bio-demographic and maternal characteristics. BMC Pediatrics, 15(36): 1-12. https:- //doi.org/10.1186/s12887-015-0349o.

Amuka JI, Asogwa FO, Ugwuanyi RO, Onyechi $T$ (2019). Health care for women international neonatal deaths and challenges of public health: Where do We need urgent intervention in developing countries? Health Care for Women International, 41(1): 1-11. https://doi.org/10.1080/o7399332.2019.1691213.

Anggondowati T, El-mohandes AAE, Qomariyah SN, Kiely M, Ryon JJ, Gipson RF, Zinner B, Achadi A, Wright LL (2017). Maternal characteristics and obstetrical complications impact neonatal outcomes in Indonesia: a prospective study. BMC Pregnancy and Childbirth, 17(1): 1-12. https://doi.org/10.1186/s12884-0171280-1.

Azizah A, Adriani M (2018). Tingkat kecukupan energi protein pada ibu hamil trimester pertama dan kejadian kekurangan energi kronis. Media Gizi Indonesia, 12(1): 21-26. https://doi.org/10.20473/mgi.v12i1.21-26.

Badan Kependudukan dan Keluarga Berencana Nasional, Badan Pusat Statistik (2018). Survey Demografi dan Kesehatan Indonesia 2017. Jakarta: BKKBN. https://doi.org/o910383107[pii] \r10.1073/pnas.0910383107

Curtis GB (1999). Your Pregnancy after 30. Fisher Books.

Demelash H, Motbainor A, Nigatu D, Gashaw K, Melese A (2015). Risk factors for low birth weight in Bale zone hospitals, South-East Ethiopia: a case - control study. BMC Pregnancy and Childbirth, 15(264): 1-10. https://doi.org/10.1186/s12884-015-0677$\mathrm{y}$.

Dinas Kesehatan Karanganyar (2019). Profil Kesehatan Kabupaten Karanganyar 
Sukoco et al./ Contextual Effect of Village and Sociodemographic Factors on Neonatal Death

Tahun 2018. Karanganyar: Dinkes Karanganyar.

Dinas Kesehatan Propinsi Jawa Tengah (2019). Profil Kesehatan Propinsi Jawa Tengah Tahun 2018 . Semarang: Dinkes Jateng.

Garba BI, Muhammad A, Mohammed B, Obasi A, Adeniji A (2017). A study of neonatal mortality in a specialist hospital in Gusau, Zamfara, NorthWestern Nigeria. Int $\mathrm{J}$ Trop Dis Health. 28(2): 1-6. https://doi.org/10.9734/IJTDH/2017/38337.

Helova A, Hearld KR, Budhwani H (2016). Associates of neonatal, infant and child mortality in the Islamic Republic of Pakistan: A multilevel analysis using the 2012 - 2013 Demographic and Health Surveys. Maternal and Child Health Journal, 21(2): 367-375. https://doi.org/10.1007/s10995-0162121-y.

Kaboré R, Bertrand I, Koulidiati JE, Millogo T, Kouanda S (2016). Factors associated with very early neonatal mortality in Burkina Faso: a matched case-control study. Int $\mathrm{J}$ Gynecol Obstet. 135: S93-S97. https://doi.org/10.1016/j.ijgo.2016.08.017.

Kc A, Kumar A, Mahendra J, Shrestha P, Zhou H, Gurung A (2019). Trends for Neonatal Deaths in Nepal (2001 2016) to Project Progress Towards the SDG Target in 2030, and Risk Factor Analyses to Focus Action. Maternal and Child Health Journal, 24: 5-14. https://doi.org/10.1007/s10995-01902826-o.

Kementerian Kesehatan Republik Indonesia (2018). Profil Kesehatan Indonesia 2018. Jakarta: Kemenkes. https://doi.org/10.1002/qj.

Kementerian Kesehatan Republik Indonesia (2010). Pedoman umum pengembangan desa dan kelurahan siaga aktif. Jakarta: Pusat Promosi Kesehatan.

Maniruzzaman Md, Suri HS, Kumar N, Abedin MM, Rahman MJ, El-Baz A, Bhoot M, Teji JS (2018). Risk factors of neonatal mortality and child mortality in Bangladesh. Journal of Global Health, 8(1): 010421. https://doi.org/10.7189/jogh.08.010421

Manuaba I, Manuaba I, Manuaba I (2009). Memahami kesehatan reproduksi wanita. Jakarta: EGC.

Maretalinia dan Wibowo (2019). Analysis of transformation alert villages program to active alert villages program in Ogan Ilir Regency in 2015. Aloha International Journal of Management Advancement, 1(1): 5-11.

Mekonnen Y, Tensou B, Telake DS, Degefie T, Bekele A (2013). Neonatal mortality in Ethiopia: trends and determinants. BMC Public Health, 13(483): 1-14.

Meltzer HM, Brantsæter AL, Nilsen RM, Magnus $\mathrm{P}$, Alexander $\mathrm{J}$, Haugen $\mathrm{M}$ (2011). Effect of dietary factors in pregnancy on risk of pregnancy complications: results from the Norwegian Mother and Child Cohort Study 1 - 4. The American Journal of Clinical Nutrition, 94(6): 1970-1974. https://doi.org/10.3945/ajen.110.001248.197 oS.

Moore VM, Davies MJ, Wilson KJ, Worsley A, Robinson JS (2004). Dietary composition of pregnant women is related to size of the baby at birth. Journal Of Nutrition, 134(7): 1820-1826. https://doi.org/10.1016/B978-0-12-384947-2.00494-3.

Nurahmawati D, Salimo H, Dewi YLR (2017). Effects of maternal education, psychosocial stress, nutritional status at pregnancy, and family income, on birthweight in Nganjuk, East Java. 
Sukoco et al./ Contextual Effect of Village and Sociodemographic Factors on Neonatal Death

Journal of Maternal and Child Health, 2(4): 327-337. https://doi.org/10.26911/thejmch.2017.02.04.04.

Nurmayanti R, Salimo H, Dewi YLR (2017). Effects of maternal nutrition status, maternal education, maternal stress, and family income on birthweight and body length at birth in Klaten, Central Java. Journal of Maternal and Child Health, 02(04): 298-309. https://doi.org/10.26911/thejmch.2017.02.04 .04 .

Paramitasari NM, Salimo H, Murti B (2018). The effect of biological, social, economic, and nutritional factors on low birth weight: A new path analysis evidence from Madiun Hospital, East Java, Indonesia. Journal of Maternal and Child Health, 3(3): 166-175. https://doi.org/10.26911/thejmch.20 18.03.03.01.

Pinem S (2009). Asuhan Kebidanan Ibu Hamil. Yogyakarta: Nuha Medika.

Prawirohardjo S (2009). Ilmu kebidanan. Jakarta: Yayasan Bina Pustaka Sarwono Prawirohardjo.

Puspitaningrum EM (2018). Hubungan Status Gizi Ibu Hamil dengan kejadian berat Badan Lahir Rendah (BBLR) di RSIA Annisa Jambi Tahun 2018. Scientia Journal, 7(2): 1-7. https://doi.org/10.5281/scj.v7i2.67.

Shibre G, Idriss-wheeler D, Yaya S (2020). Inequalities and trends in Neonatal Mortality Rate (NMR) in Ethiopia: Evidence from the Ethiopia Demographic and Health Surveys, 20002016. PLoS ONE, 15(6): 1-10. https://doi.org/10.1371/journal.pone.0234 483.

Sulaeman ES, Karsidi R, Murti B, Kartono DT, Waryana W, Hartanto R (2012). Model pemberdayaan masyarakat bidang kesehatan, Studi program desa siaga. Jurnal Kesehatan Masyarakat Nasional, 7(4): 186-192. https://doi.org/10.21109/kesmas.v7i4.54.

Surya FH, Sunarto (2016). Analysis of independent active Alert Village in Tridadi Village, Sleman, D.I. Yogyakarta Province. Jurnal Kedokteran Dan Kesehatan Indonesia, 7(4): 125-131. https://doi.org/10.20885/JKKI.Vol7.Iss4. art2.

Suryani (2011). Hubungan tingkatan desa siaga dengan angka kematian bayi di Kabupaten Blitar Jawa Timur Tahun 2010. Jakarta: FKM Universitas Indonesia.

Trisnawati I, Salimo H, Murti B (2018). Biopsychosocial and economic determinants of low birth weight in Jambi, South Sumatera: Path Analysis. Journal of Maternal and Child Health, 3(1): 1-10. https://doi.org/10.26911/thejmch.2017.03.01.01.

WHO (2019). Newborns: improving survival and well-being. Retrieved from https://www.who.int/en/news-room/fact-sheets/detail/newborns-reducing-mortality

Wigunantiningsih A, Fakhidah LN (2017). Faktor-faktor yang mempengaruhi kejadian anemia ibu hamil trimester III pada kunjungan ANC di Stikes Mitra Husada Karanganyar. Jurnal Maternal, 2(2): 126-132.

Wigunantiningsih A, Fakhidah LN (2017). Faktor internal yang mempengaruhi berat badan lahir bayi di Kabupaten Karanganyar. Jurnal Maternal, 2(1): 7-15.

Wu Q, Li L, Li J, Zhou C, Huang Y (2016). Time trends of neonatal mortality by causes of death in Shenyang, 19972014. Oncotarget, 7(13): 1661016618. doi: 10.18632/oncotarget.7670. 